\title{
THE EU'S ALTERNATIVE ROUTES TO ESCAPE THE JOINT DECISION TRAP: AN ASSESSMENT IN THE AFTERMATH OF THE 2015 REFUGEE CRISIS
}

\author{
Elif Cemre BEŞGÜR* \\ Research Article**
}

\begin{abstract}
After a failed attempt to reform the Dublin III Regulation, the European Commission presented the New Pact on Migration and Asylum in September 2020, aiming to abolish the Dublin Regulation. Although the policy-core remains unchanged, a consensus has not yet been reached on it. In this context, the research focuses on informal ways to cooperate for escaping what Scharpf (1998) calls "the joint decision trap". Based on this theoretical premise, the article assesses whether exit mechanisms are adequate in resolving the deficiencies of the Common European Asylum System or not. The article argues that exit mechanisms only address the deficiencies to a limited extent. Therefore, they are far from compensating for the lack of reform and constituting a basis for long-term solutions.
\end{abstract}

Keywords: The Joint Decision Trap, the European Union, Dublin System, Asylum and Migration Policies.

* $\mathrm{Bu}$ makale, Elif Cemre Beşgür'ün Jean Monnet Burs Programı kapsamında Vrije Universiteit Brussel'da 2020 yılında Florian Trauner danışmanlığında yazdığı yüksek lisans tezinden üretilmiștir. Çalışmanın genişletilmiş özeti Jean Monnet Burs Programı tarafından Jean MonneThesis derginde yayımlanmıştır. /This article is developed from master's thesis written by Elif Cemre Beşgür under the supervision of Florian Trauner at Vrije Universiteit Brussel in 2020 as part of the Jean Monnet Scholarship Program. An extended abstract of this study has been published by the Jean Monnet Scholarship Program in the journal Jean MonneThesis.

** PhD Researcher, University of Trento, School of International Studies, Trento-Italy, email: elifbesgur@gmail.com, ORCID: 0000-0003-2739-1462.

Makalenin Gönderilme Tarihi: 04/03/2021 Kabul Edilme Tarihi: 07/09/2021 


\section{AB'nin Ortak Karar Tuzağından Kaçmak için Alternatif Yolları: 2015 Mülteci Krizi Sonrasında Bir Değerlendirme}

\section{$\ddot{O} z$}

Dublin III Tüzüğ̈̈’nün reform girişimleri başarısız olduktan sonra, Avrupa Komisyonu Eylül 2020'de Dublin Tüzüğ̈̈'nü yürürlükten kaldırmayı amaçlayan Yeni Göç ve Iltica Paktı'nı sunmuştur. Teklifte politikanın özü değişmeden kalmasına rağmen, üzerinde henüz bir fikir birliğine varllmamıştır. Bu bağlamda makale, Scharpf'ın (1998) “ortak karar tuzăğ ” dediği durumdan kaçmak için gayri resmi iş birliği yollarına odaklanmaktadır. Bu teorik anlayış çerçevesinde makale, Avrupa Ortak Iltica Sistemi'nin eksikliklerinin giderilmesinde çıkış mekanizmalarının yeterli olup olmadı̆̆ını değerlendirmektedir. Makale, çıkış mekanizmalarının sisteminin eksikliklerini yalnızca sınırlı ölçüde ele aldı̆̆ını savunmaktadır. Bu nedenle, söz konusu mekanizmalar, reform eksikliğini telafi etmekten ve uzun vadeli çözümler için bir temel oluşturmaktan uzaktır.

Anahtar kelimeler: Ortak Karar Tuzağl, Avrupa Birliği, Dublin Sistemi, Iltica ve Göç Politikaları.

\section{Introduction}

The departure point of this article is the fragile design of European Union (EU) asylum policies. In this regard, the migration and refugee crisis that manifested itself in 2015, represented a turning point in the history of the EU and uncovered already-existing problems. This, combined with several terrorist attacks on European soil, led to a political debate on migrants and refugees that caused a heated and polarised political landscape in Europe. Therefore, finding a common policy on migration has proved difficult for EU leaders. ${ }^{1}$

Even though the situation itself eventually led to an increased focus on reforming the Dublin system, it has not been possible to proceed due to the divergent positions of the EU member states in the Council. This is described by the German scholar Fritz Scharpf as "the joint decision trap" (JDT) which is the situation that common decisions are blocked unilaterally by the member state or a group of member states through the lowest

1 Natascha Zaun and Christof Roos. "Immigration Policy and European Union Politics." Oxford Research Encyclopedia of Politics, Oxford: Oxford University Press, 2019. 
common denominator approach. ${ }^{2}$ Although the member states are not able to proceed with legislative changes in the field of asylum, different routes for moving forward still can be possible. In this framework, this research seeks to analyse the following questions: To what extent has the EU managed to mitigate the deficiencies of the Dublin System in the wake of the migration crises? How can the EU make asylum policies more efficient without the proper opportunity to make it so?

In this regard, the article will focus on exit mechanisms that provide an informal way to cooperate in order to escape the JDT. In the academic literature, the implications of the JDT have been studied in different fields. ${ }^{3}$ In terms of migration-related policy fields, this issue has been discussed within the context of the return policy ${ }^{4}$ and the Prüm process. ${ }^{5}$ However, this topic has received scant attention in the literature within the context of the Dublin system deficiencies. In addition, analysing this issue is a research desideratum as the 2015 migration crisis might not be an exception and may happen again and on an even larger scale. If Europe cannot handle one million, there is no reason to believe that it will deal with an even larger number. This also represents the rationale and legitimacy of this research.

In terms of structure, the article develops its argument in three steps. Firstly, it starts by looking at the JDT theory which implies the high possibility of having a stalemate in the policymaking process of the EU. ${ }^{6}$ Secondly, the attention shifts to the overview of asylum policies and its deficiencies with reference to the JDT theory. Having explained the theory and deficiencies of the Dublin system, the article investigates alternative routes to break the JDT through different case studies: Malta Agreement, 18

2 Fritz W. Scharpf, "The Joint-Decision Trap: Lessons from German Federalism and European Integration", Public Administration 66, no 3 (1998): 239-278; Fritz W. Scharpf, "The joint decision trap model: context and extensions" in The EU's Decision Traps: Comparing Policies, ed. Gerda Falkner, pp. 217-237, Oxford: Oxford University Press, 2011.

3 Gerda Falkner (ed.), The EU's Decision Traps: Comparing Policies, Oxford University Press, 2011.

4 Peter Slominski and Florian Trauner, "Reforming me softly - how soft law has changed EU return policy since the migration crisis", West European Politics 44, no 1 (2020): 93-113.

5 Florian Trauner, "Increased Differentiation as an Engine for Integration" in The EU's decision traps: comparing policies, Gerda Falkner (ed.), pp. 145-160. Oxford: Oxford University Press, 2011.

6 Scharpf (1998); Fritz W. Scharpf, “The Joint-Decision Trap Revisited”, JCMS: Journal of Common Market Studies 44, no 4 (2006): 845-864. 
March EU-Turkey Statement and the Attitude of Hungary. While the second section attempts to assess why it is difficult to decide on asylum, the third section analyse how this has changed in the aftermath of the Syrian Refugee Crisis through case-study approach. Lastly, the conclusion attempts at assessing the efficiency of the EU's crisis response. The conclusion presents the findings of the research, recaps the arguments with the aim to answer the research questions, and reflects upon the future of the EU in the asylum field.

\section{Joint Decision Trap Theory}

Jean Monnet, who is one of the founding fathers of the EU, argues that "Europe will be forged in crises and will be the sum of the solutions adopted for those crises". ${ }^{7}$ This is not always the case due to the JDT. Scharpf uses the decision-making procedure of German federalism and the unanimous voting procedure of the EU to find similarities that lead to a JDT. In his analysis, he identifies two conditions for applying JDT:

"(1) central government decisions are directly dependent upon the agreement and (2) the agreement of constituent governments must be unanimous or nearly of constituent governments; and unanimous". ${ }^{8}$

The dependency of central level government upon the constituent governmental levels, causes of a deadlock in policymaking processes. ${ }^{9}$ In terms of unanimous decision making, he states that since all actors have the right to veto, reaching a consensus will be difficult and will likely be blocked. ${ }^{10}$ This explains why the JDT occurs.

Taking into account the historical context of Scharpf's research of 1998, German federalism and the EU met these two conditions. The Council of Ministers, which serves the interest of the member states, represents the main source of power. In addition, under the unanimous decision-making procedure, member states have the veto power to block common policies. Member states are driven by national interests, and as such, it becomes

7 Jean Monnet, Memoirs, translation. R. Mayne Garden City: Doubleday \& Company, 1978, p.417, cited Gerda Falkner, "The EU's current crisis and its policy effects: research design and comparative findings", Journal of European Integration 38, no 3 (2016): p. 219.

8 Scharpf, 1998, p. 254.

9 Ibid., p. 242.

10 Ibid., p. 257. 
difficult to take action or show a quick response against external shocks. As a result, vulnerabilities may arise. In the case of the EU, and member states transferring some of their competences to the supranational institutions, they cannot act solely in accordance with their national interests. However, the EU itself cannot act either due to the fact that member states depend on their national interests in the EU decision-making process. However, even though multilevel decision-making systems tend to fall into the JDT due to the aforementioned reasons, this does not mean that the situation of the JDT is permanent. ${ }^{11}$ Agreements promoting "logrolling", "package deals" and "side payments" are common. ${ }^{12}$ Moreover, the changing dynamics of European integration may offer decision-makers different routes to avoid JDT. In this regard, Peters points at "the division of decisions into functional specialities". ${ }^{13}$ According to him, the subdivisions in the Council and the Commission provide an opportunity for policy entrepreneurs to structure their own decision. ${ }^{14}$ These instruments will facilitate the reaching of an agreement. However, even if this is the case, overcoming the JDT should not be taken for granted due to the institutional design and decision-making systems. ${ }^{15}$

What is striking is that it was more than 30 years ago that Scharpf proposed the concept. During this period, the EU has experienced unprecedented changes such as numerous treaty amendments, increasing number of member states, simplifying the decision-making process, the growing role of the EP etc. Given sufficient consideration of these changes, at first glance, these changes may give the impression that the JDT argument is no longer valid. However, in light of the gained dynamism of European integration, Scharpf re-evaluated his initial explanation of JDT in 2006. This time, he introduces three modes of European governance to understand the JDT practices better: (1) "intergovernmental mode" in which the JDT is relevant due to the fact that national governments are in power; (2) the "joint-decision mode" which is a combination of "intergovernmental negotiations and supranational centralisation" application of the JDT is

11 Ibid., p. 264.

12 Ibid., p. 264.

13 B. Guy Peters, "Escaping the joint-decision trap: Repetition and Sectoral politics in the European Union", West European Politics 20, no 2 (1997), p. 22.

14 Ibid., pp. 22-23.

15 Scharpf, 2006, p. 856. 
defined by the context and (3) the "supranational-hierarchical mode" in which the JDT is not applicable thanks to the Commission's honest broker role, the ECJ or the European Central Bank's ability to operate policymaking functions. ${ }^{16}$ Concisely, the application of the Community method is critical to circumvent from the JDT.

However, his argument has not escaped criticism from other academics. One criticism stemming from much of the literature is the "static nature" of JDT. ${ }^{17}$ According to Pollack, due to its focus on certain decision-making modes and procedures, the JDT model is limited in explaining different policy types such as distributive, regulatory and redistributive policies of the EU. ${ }^{18}$ In addition, the JDT has been subject to considerable criticism in terms of analysing member states willingness to escape the JDT. According to Müller and Slominski, the classical JDT understanding frames actor preferences as given and relatively invariant with reference to the national interest. ${ }^{19}$ However, this approach overlooks "inter-temporal choice", explaining how decisions are made in terms of "trade off costs and benefits associated with a certain policy at different points in time". ${ }^{20}$

As a response to the critiques, Scharpf extended the JDT concept to increase its explanatory power by including the Commission and the ECJ as strategic actors. ${ }^{21}$ On the one hand, he highlights the strategic influence of the Commission with reference to its legislative power and the threat of infringement procedures to influence joint decision negotiations in the extended version of the JDT. ${ }^{22}$ On the other hand, the judgments of the ECJ are essential in terms of providing an exit from the JDT. ${ }^{23}$ In addition to these factors incorporating the JDT model, he put emphasis on the creation of the JDP as a consequence of legislation itself. According to him, "when

\footnotetext{
16 Ibid., pp. 847-856.

17 Mark A. Pollack, "Creeping competence: the expanding agenda of the European Community”, Journal of Public Policy 14, no 2 (1994): 95-145; Patrick Müller and Peter Slominski, "Agree now - pay later: escaping the joint decision trap in the evolution of the EU emission trading system", Journal of European Public Policy 20, no 10 (2013): 1425-1442.

18 Pollack, 1994, pp.101-102.

19 Müller and Slominski, 2013, p. 1428.

20 Müller and Slominski, 2013, p. 1428.

21 Scharpf, 2011.

22 Ibid., pp. 229-230.

23 Ibid., p. 227.
} 
European legislation is writing on a clean slate", the inability to attain consensus leaves member states free to follow their own interests autonomously. ${ }^{24}$ In other words, as long as the area of legally binding European law expands, the domain to which the JDT model applied is also expanding. ${ }^{25}$

\section{The Dublin System and the Joint Decision Traps}

First of all, in the global context, the 1951 Geneva Convention is the foundation of the international refugee protection regime. In the European context, the Dublin system is the main pillar of the Common European Asylum System (CEAS). According to Article 1 of the Dublin Convention, its main function is to determine the member states responsible for asylum applications by third-country nationals or stateless persons who wish to enter the EU. ${ }^{26}$ The Dublin system has been in force since the 1990s which was transferred to Dublin II $^{27}$ in 2003 and revised to Dublin III Regulation ${ }^{28}$ in 2013.

In line with the recent experiences stemming from the Syrian Refugee Crisis, the Commission first put forward a proposal for the recast of the Dublin III Regulation in 2016. However, its recast so-called Dublin IV regulation was blocked in the Council due to the divergences between member states over mandatory reallocations to ensure fair burden-sharing. Indeed, this represents the JDT in the asylum field. Recently to solve this deadlock, the Commission has withdrawn its initial proposal on the reform of the Dublin Regulation and proposed the New Pact on Migration and Asylum in September 2020 that aims to abolish the Dublin Regulation and replace it with Regulation on Asylum and Migration Management. ${ }^{29}$

In relation to the theory of JDT, this section attempts to assess why it is difficult to decide on Dublin system and sources of the JDT in the field of

24 Ibid., p. 222.

25 Ibid., p. 223.

26 Convention Determining the State Responsible for Examining Applications for Asylum Lodged in One of the Member States of the European Communities, OJ C 254/01, 1990.

27 Council Regulation (EC) No 343/2003.

28 Council Regulation (EU) No 604/2013.

29 Please See. European Commission, "Communication from the Commission to the European Parliament, the Council, the European Economic and Social Committee and the Committee of the Regions on a New Pact on Migration and Asylum", COM(2020) 609 final, 23 September 2020, Brussels. 
asylum. The article argues that three discrete reasons emerged from this. The first reason for the JDT in the Dublin system is related to the policy nature of the asylum field. The Dublin Convention, and other migration and asylum competences were gradually integrated into the EU legal framework. Since asylum is a sensitive issue, the member states were relatively reluctant to cooperate and delegate their sovereignty to the EU level at the beginning. ${ }^{30}$ This is the reason why initial cooperation took place outside of the EU's legal framework. However, currently, cooperation in this field is communitarised as a shared competence between the member states and the EU. The overarching objective, established in Paragraph 1 of Article 79 of the TFEU, demonstrates the EU's willingness to develop a relatively ambitious common policy on asylum in terms of harmonisation of objectives. Nevertheless, the same Article, Paragraph 5, underlines the fact that member states are the key actors in terms of determining the volume of admissions of third-country nationals. However, the Commission has been persistently trying to develop a comprehensive asylum regime with reference to the principle of solidarity, laid down in Article 80 in TFEU, which implies helping and support one another. By doing so, the Commission is attempting at creating a common ground between the member states. ${ }^{31}$

Recently, this situation manifested itself in the context of the New Pact. The Commission desires to address imbalances by adopting a more flexible approach concerning the principle of solidarity. Compared to the recast proposal in 2016, the New Pact ends strict mandatory focus on relocation of asylum seekers. It provides member states flexibility to choose either relocating asylum seekers or engaging in return called as "return sponsorship" -a new form of solidarity contribution- in the New Pact. ${ }^{32}$ Additionally, the member states may even choose the nationalities that they want to sponsor ${ }^{33}$. However, many uncertainties come along with this flexibility. From the member states' side, it is not certain how and under what conditions the member state will contribute. From the side of the

30 Emek M. Uçarer, "Justice and Home Affairs" in European Union Politics, Michelle Cini and Nieves Perez-Solorzano Barragán (eds)., 3rd ed, Oxford: Oxford University Press, 2010, p. 307.

31 Andrew Geddes, "Migration: differential Institutionalisation and Its Effect" in Policy Change in the Area of Freedom, Security and Justice: How EU Institutions Matter, Florian Trauner and Adriana Ripoll Servent (eds.), London: Routledge, 2015, p. 73.

32 European Commission, 2020, pp. 5-6.

33 Ibid. 
Commission, given the flexibility and the lack of incentives, sanctions and enforcement mechanisms vis-à-vis the member states, it is relatively vague that how the Commission and the solidarity mechanism itself will work in practice. ${ }^{34}$ Moreover, the Commission proposed to decide under the time of crises according to "holistic qualitative assessment" without clear indicators that further blur the operationalisation of the system ${ }^{35}$. There is no doubt that these uncertainties will also have implications concerning human rights and creating new vulnerabilities.

Translating into this to the theory means what Scharpf call the "jointdecision mode" is active where intergovernmental negotiations are associated with supranational centralisation in which "very high consensus requirements and the heterogeneity of member state interests and preferences would make agreement difficult or impossible". ${ }^{36}$ To give another example, the reallocation scheme was proposed by the Commission in the aftermath of the Syrian Refugee Crisis based upon Article $80 .{ }^{37}$ However, Hungary and Slovakia do not fulfil their obligations concerning the relocation scheme despite the Court's decision and the ongoing infringement procedure. ${ }^{38}$ As Slominiski and Trauner argue, the EU level has only a partially integrated view. ${ }^{39}$ Therefore, there is still more room for possibility of cooperation and freeriding of member states. The JDT theory states that the degree of conflict between the actors increases the difficulty of reaching consensus. ${ }^{40}$ Therefore, the JDT is likely to take place, apart from the communitarisation of the asylum field and relatively ambitious objectives.

34 Olivia Sundeberg Diez and Florian Trauner, "EU return sponsorships: High stakes, low gains?”, EPC Discussion Paper, 19 January 2021, p.10.

35 European Commission, "Proposal for a Regulation of the European Parliament and of the Council on asylum and migration management and amending Council Directive (EC) 2003/109 and the proposed Regulation (EU) XXX/XXX [Asylum and Migration Fund]", $\operatorname{COM}(2020) 610$ final, Brussels, p. 12.

36 Scharpf, 2006, p. 854.

37 European Commission, "Relocation: EU Solidarity Between Member States", Press Release November 2017, https://ec.europa.eu/home-affairs/sites/homeaffairs/files/whatwe-do/policies/european-agendamigration/20171114_relocation_eu_solidarity_between_member_states_en.pdf, (22.09.2020).

38 Court of Justice of the European Union, "Slovak Republic and Hungary v Council of the European Union", Judgement of the Court of C-643/15 and C-647/15, 6 September 2017.

39 Slominiski and Trauner, 2020, p. 96.

40 Scharpf, 2011, p. 231. 
Secondly, as Scharpf argues, the JDT becomes active under circumstances where member states' interests diverge; in a such a situation, cooperation may either fail or the states will secure a partial consensus. ${ }^{41}$ In the case of the Dublin system, heterogeneous interests existed between member states depending on their geographical location. According to the European Commission, the default rule is the one most frequently applied, rather than hierarchy criteria due to the fact that most asylum seekers do not have prior links with the EU member states. ${ }^{42}$ However, this is problematic because the default rule puts a disproportionate share of responsibility on those states located at the EU's external borders and has caused contestation. On the one hand, EU member states located on the external borders, in particular, southern member states are obliged to act as a "gatekeeper" for the sake of implementation of Dublin rules. ${ }^{43}$ On the other hand, according to Trauner, if the Dublin rules are rejected at the expense of responsibility sharing for the sake of southern states, it risks overburdening northern member states. ${ }^{44}$ While member states located on the EU's external borders are in favour of reform to share the burden of the relocation of asylum seekers, northern member states in particular are in favour of keeping their advantageous position of receiving as few asylum seekers as possible. Therefore, the divergence of interest between the member states is omnipresent and paves the road for member states to go into a decision trap. This can be seen in the case of the New Pact as well. The member states those choosing the return option instead of reallocation, the concept of return sponsorship indicates that they have eight months to return or remove irregular migrants; if not, member states are obliged to transfer the asylumseekers to their own country. ${ }^{45}$ On the one hand, from the perspective of cooperation reluctant member states such as Austria and Hungary, this is

41 Ibid., p. 223.

42 European Commission, "Communication from the Commission to the European Parliament and the Council towards a Reform of the Common European Asylum System and Enhancing Legal Avenues to Europe", COM (2016) 197 final, Brussels, p. 12.

43 Florian Trauner, "Asylum policy: the EU's 'crises' and the looming policy regime failure", Journal of European Integration 38, no 3 (2016): p. 321.

44 Ibid., pp. 321-322.

45 European Commission, "Proposal for a Regulation of the European Parliament and of the Council on asylum and migration management and amending Council Directive (EC) 2003/109 and the proposed Regulation (EU) XXX/XXX [Asylum and Migration Fund]", p. 22. 
seen as a "relocation through the back door" under limited time ${ }^{46}$. On the other hand, the EU bordering states such as Malta and Greece states that eight months is a very long period; it should be shortened as a standard. ${ }^{47} \mathrm{In}$ this sense, as the political cleavages between the member states are apparent over responsibility-sharing, the New Pact is unlikely to bridge these divisions. Thus, there is also quite a high risk that the negotiations would be very polarized and member states find themselves in a JDT.

This situation is also closely associated with the theoretical framework of historical institutionalism. Historical institutionalism explains the policy process as "path dependent". ${ }^{48}$ The Dublin system and the contracting member states find themselves in a JDT as a result of path dependency. Path dependency means that as soon as the institutions, rules and norms are created it gets more difficult to change and go back to the status quo. Pierson refers to this as "stickiness" in which rules are historically established and renders what is termed path dependency. ${ }^{49}$ In this regard, which is important to keep in mind, even though the Dublin Convention was initially signed in 1990, the discussions on the Dublin Convention took place in the 1980s. This was a time when spontaneous migration influx was low as a result of the geopolitical situation in the era of the Iron Curtain which refers to the period between $1945-1990 .{ }^{50}$ This could perhaps be the reason why policymakers did not think about how the system would operate if, and when, larger migrant arrivals encountered. Due to the "stickiness" brought about by path dependency ${ }^{51}$, blocks meaningful reforms to the core idea of the responsibility sharing system, despite a substantial increase in the number of asylum seekers throughout the time. As classical JDT theory argues, "agreement on European legislation dealing with pressing policy problems would be difficult to reach and, once adopted, that it would be even more difficult to change". ${ }^{52}$ However, the basis of this argument is on

46 Sundeberg-Diez and Trauner, 2021, p. 7.

47 Ibid.,

48 Paul Pierson, "Increasing Returns, Path Dependence, and the Study of Politics", American Political Science Review 94, no 2 (2000): p. 251.

49 Paul Pierson, "The Path to European Integration: A Historical Institutionalist Analysis", Comparative Political Studies 29, no 2 (1996): 123-163.

50 Neill Nugent, The Government and politics of the European Union, London: Palgrave, 1999, p. 13.

51 Pierson, 1996, p. 143

52 Scharpf, 2011, p.231. 
the fact that member states are often in favour of promoting heterogenous interest to defend their own self-interest which makes the change of decision difficult. ${ }^{53}$ Therefore, this inability to agree on a common solution leaves member states locked in a JDT.

Third, the politicisation of migration in member states reinforces the JDT. Migration is perceived as a salient topic in member states national politics. As Zaun and Roos claim that the refugee crisis increased the saliency of the issue among the public and pushed governments "to act in full capacity of their sovereign control over migration." ${ }^{54}$ In this regard, it is a well-known fact that solidarity problems between the EU member states exist. Zaun argues that as a result of the rise of populism and anti-immigrant sentiment in Visegrad countries, a shift occurred in the direction of countries adopting restrictive policies in the migration and asylum field, resulting in the rejection of any binding European solutions. ${ }^{55}$ While the explanations offered through the above analysis clarifies the difficulties in proceeding together on the legislative basis for common asylum procedures and finding common European solutions to the Dublin system, this does not mean that the situation of the JDT is inescapable. In this regard, the next section will analyse the different mechanisms to escape the JDT and evaluate member states' different attempts to escape it in the field of asylum.

\section{Escaping from the Trap in the Asylum Field}

Applied to the Justice and Home Affairs (JHA) field, Trauner lists three exit mechanisms in order to escape the JDT. ${ }^{56}$ The first one is "change of decision rule" which is related to gradual communitarisation of the policy field. He holds the view that, gradual communitarisation of the policy field led to the inclusion of the supranational actors with limited competences. Also, the introduction of the different decision-making rules (opt-outs) paved the way for willing member states and transitional periods caused the loss of the "culture of consensus." 57

53 Scharpf, 2011, p.231.

54 Zaun and Roos, 2019, p. 15.

55 Natascha Zaun, "States as Gatekeepers in EU Asylum Politics: Explaining the Nonadoption of a Refugee Quota System", JCMS: Journal of Common Market Studies 56, no 1 (2018): pp. 46-48.

56 Trauner, 2011.

57 Ibid., pp. 150-151. 
The second exit option is the "EU-induced change of opportunity structure" for undermining the position of the veto player. Launching enhanced forms of cooperation outside of the legal framework which contributed to the introduction of differentiated forms integration is seen as the essential form in terms of undermining the veto-player ${ }^{58}$ In this regard, differentiated integration serves as a mechanism in which different groups of member states are allowed to cooperate outside of the EU legal framework to manage heterogeneity within the EU and overcome decision deadlocks. ${ }^{59}$

The last exit option consists of a variety of mechanisms that can potentially support the consensus to exit the JDT. They are as follows: unexpected external events, Europeanization of national problems, enlargement of package deals, burden-shifting, the prevalence of "negative" integration forms, opt-outs and exceptions. ${ }^{60}$

Building on this theoretical ground, the study addresses three case studies (Table 1). These case studies are evaluated as exit mechanisms and designed to explain how the EU and member states attempt through different arrangements outside of the EU legal framework. With regard to EU-induced changes of opportunity structure, the case study of the Malta Agreement will demonstrate the introduction of the temporary solidarity mechanism for assisting those rescued at sea as a differentiated form of integration. Next, the case study of EU-Turkey Statement will explain how member states undermine the supranational institutions to break the JDT for blocking the migration route. Lastly, non-compliant attitude of Hungary will be analysed as an exception to demonstrate how the member states act unilaterally where no other possibility is envisioned at the national level.

\footnotetext{
58 Ibid., p. 154.

59 For more detailed explanation on differentiated integration please see. Alexander Stubb, "A Categorization of Differentiated Integration", Journal of Common Market Studies 34, no 2(1996): pp. 283-285; Frank Schimmelfennig, Dirk Leuffen and Berthold Rittberger, "The European Union as a system of differentiated integration: interdependence, politicization and differentiation", Journal of European Public Policy 22, no 6 (2015): pp. 765-767; Elif C. Beşgür and Utku Utkulu, "Esnek Entegrasyon Temelinde Avrupa Birliği'nin Geleceği ve Türkiye'nin Yeri: Muhtemel Senaryolar" Ankara Avrupa Çalışmaları Dergisi 18, no 2(2020) pp. 327-331.

60 Trauner, 2011, pp.154-156.
} 
Table 1: Escaping the Joint-Decision Trap in the Field of Asylum

\begin{tabular}{|c|c|c|c|}
\hline $\begin{array}{c}\text { Exit } \\
\text { Mechanism }\end{array}$ & $\begin{array}{c}\text { Relevant } \\
\text { Approach }\end{array}$ & Case Studies & Consequences \\
\hline $\begin{array}{c}\text { EU-induced } \\
\text { changes of } \\
\text { opportunity } \\
\text { structure }\end{array}$ & $\begin{array}{c}\text { European Approach } \\
\text { Cooperation with } \\
\text { Third Countries }\end{array}$ & $\begin{array}{c}\text { Malta Agreement } \\
\text { Statement of } 18 \\
\text { March }\end{array}$ & $\begin{array}{c}\text { Differentiated form } \\
\text { of Integration }\end{array}$ \\
\hline $\begin{array}{c}\text { Other } \\
\text { mechanisms: } \\
\text { Exceptions }\end{array}$ & Unilateral Approach & $\begin{array}{c}\text { The Attitude of } \\
\text { Hungary }\end{array}$ & Closing Border \\
\hline Souration
\end{tabular}

Source: own elaboration based on Trauner 2011

\section{A. Case Study One: Malta Agreement}

The Malta Agreement demonstrated how member states manage to partially exit the JDT through the signing of an informal agreement outside the EU legal framework. This occurs in spite of the opposition to the reform of the CEAS in the Council. On 23 September 2019, four European countries, Germany, Malta, France and Italy, reached a consensus on the acceptance and distribution of eligible asylum seekers those trying to reach Europe by crossing the Central Mediterranean to seek international protection. The outcome of the consensus was "the Malta Agreement." 61 This agreement is neither an international agreement, nor an EU legislative act; but rather a "joint declaration" agreed at an informal summit with the participation of the Council's Finnish Presidency and the EU Commissioner for Migration, Dimitris Avramopoulos. In fact, it was named "Joint declaration of intent on a controlled emergency procedure - voluntary commitments by member states for a predictable temporary solidarity mechanism". As such, the Malta Agreement can be seen as a practice of a soft law approach with a flexible nature that has limited legal impacts and potential to create practical impacts.

In accordance with the agreement, the main objective is to "set up a more predictable and efficient temporary solidarity mechanism in order to

61 Please see. Joint Declaration of Intent on a Controlled Emergency Procedure-Voluntary Commitments by Member States for a Predictable Temporary Solidarity Mechanism, 2019, Valletta. 
ensure the dignified disembarkation of migrants taken aboard, on the high seas, by vessels in a place of safety". ${ }^{62}$ Thus, the scope of the agreement only covers asylum seekers rescued in the Mediterranean and not those crossing the Central Mediterranean singlehandedly. In the case of rescued asylum seekers who are not eligible for international protection, they will be subject to an "effective and quick return". ${ }^{63}$ If rescued asylum seekers are eligible for international protection, "the swift relocation, [...] should not take longer than 4 weeks." ${ }^{64}$ Thus, the agreement intends to demolish the principle of the first entry - a highly criticised component of the EU Dublin Regulation between participating member states.

Even though a temporary solidarity mechanism is open to other EU and Schengen member states ${ }^{65}$, the majority of the member states except Ireland, Portugal and Luxembourg, did not support the agreement. They expressed their strong rejection at the JHA Council on 8 October $2019 .{ }^{66}$ In fact, the Malta Agreement could serve "as a litmus test" in terms of relocation of asylum seekers and slowly unlock consensus on Dublin. ${ }^{67}$ The strong rejection of member states showed the complexity of reaching a consensus. Bulgaria, Cyprus and Greece criticised the agreement for not paying attention to the Eastern Mediterranean migration route and focusing solely on the central Mediterranean route. ${ }^{68}$ Additionally, the remaining member states opposed the Malta Agreement as they were against reforming the Dublin system or any other plan aiming at the distribution of asylum seekers across Europe. Consequently, the fact that only a limited number of member states reached a consensus on cooperation beyond the scope set by the Dublin system, increased differentiated integration in the field of asylum policy.

Despite the limited participation of member states, the Malta Agreement has had a positive impact. 464 rescued asylum seekers were eligible for international protection and were reallocated from Italy to other participating

62 Article 1 of Ibid.

63 Article 7 of Malta Agreement

64 Article 2 of Malta Agreement.

65 Article 3 of Malta Agreement.

${ }^{66}$ Council of the European Union, "Justice and Home Affairs Council", 7-8 October 2019.

67 Olivia Sundeberg Diez, "Diminishing safeguards, increasing returns: Non-refoulement gaps in the EU return and readmission system", EPC Discussion Paper, 4 October 2019, p.19.

68 Council of the European Union, "Outcome of the Justice and Home Affairs Council Meeting”, 12837/19, Luxembourg, 7 October 2019, p. 22. 
states within the framework of the Malta Agreement during the period of September 2019 and January 2020. ${ }^{69}$ Apart from ensuring decreased fatalities at sea, other positive effects of the agreement have been increased fight against migrant smuggling, the tackling of human trafficking through aerial surveillance, and the introduction of certain measures for vessels to guarantee the security of asylum seekers. ${ }^{70}$ In addition, rescued immigrant boats will not be kept on the agenda for a long time which means that farright movements could be prevented from increasing their political weight by taking advantage of migrants.

Despite these positive developments, the Malta Agreement has been subject to considerable criticism. First of all, the temporary solidarity mechanism is explicitly described as a "pilot project" and "valid for a period of not less than six months and may be renewed". ${ }^{71}$ In addition, in the case of misuse or a substantial increase in the number of reallocated asylum seekers, there is a possibility to suspend the entire mechanism in accordance with the consultation between participating member states. ${ }^{72}$ However, no clear definition is provided in terms of the meaning of substantial increase. Similarly, there is no clear detail regarding which criteria migrants will be selected and distributed. This has raised concerns about "ad hoc disembarkation and relocation arrangements", whether privileges will be given to certain nationalities on the basis of the political preferences of the participating member states. ${ }^{73}$

In addition to this, the Malta Agreement brings to the fore fundamental issues in terms of solidarity. Carrera and Cortinovis argue that "solidarity à la carte runs the risk of turning the clock back three decades in European integration and re-injecting nationalism and intergovernmentalism into fields." ${ }^{74}$ As Trauner states, the increased differentiation of the JHA field and the existence of complex decision-making mechanisms raises doubts

69 Andrea Catani, “The so-called "Malta Agreement”: four months later", 24 February 2020, https://www.sirius-project.eu/news/so-called-malta-agreement-four-months-later, (01.07.2020).

70 Article 12 and 13 Malta Agreement.

71 Article 15 of Malta Agreement.

72 Ibid.

73 Sergio Carrera and Roberto Cortinovis. "The Malta declaration on SAR and relocation: A predictable EU solidarity mechanism?”, CEPS Policy Insight, No. 2019-14/October 2019 , p. 4.

74 Ibid., p. 6. 
regarding the reachability of one voice "single JHA policy" 75 In light of these criticisms, one could argue that the Malta Agreement is not the best possible option for the redistribution of immigrants as fair and equal between member states. Since it is not possible to reach and install a sustainable EU solidarity mechanism, consensus reached on the Malta Agreement by a group of member states contributes, to a certain extent, a way to escape the deadlock. Lastly, the Malta Agreement shows positive results in the rescuing of asylum seekers in the Mediterranean, despite its temporary, limited and conditional nature.

\section{B. Case Study Two: The EU-Turkey Statement of 18 March}

At the time of the EU-Turkey Statement, the EU was under migratory pressure both externally and internally. Externally, the EU was facing an unstoppable migratory flow to European shores compared to the previous year. According to European Border and Coast Guard Agency (FRONTEX) data, while the number of irregular migrants was 282,962 in 2014, it increased more than six times in 2015 and reached 1,822,337. ${ }^{76}$

Internally, the problems were associated with the Temporary Emergency Relocation Scheme. ${ }^{77}$ The scheme was the attempt of the EU in cooperation with the member states to relocate refugees on a voluntary basis. Following the 2015 Syrian Refugee Crisis, the EU member states had difficulties finding a common solution in the management of mass migration flows coming into Europe. They had not reached a consensus on a common binding European mechanism. The scheme was established with the Council Decision to relocate asylum seekers up to 160.000 from Greece and Italy to other member states ${ }^{78}$-to alleviate the dire situation that these two countries found themselves in. The implementation remained insufficient due to the strong resistance from the EU member states, even though the core idea was

75 Trauner, 2011, p. 159.

76 FRONTEX, "Risk Analysis for 2017”, 2133/2017, Warsaw, p. 19.

77 Council of the European Union, "EU-Turkey Statement, 18 March 2016", https://www.consilium.europa.eu/en/press/press-releases/2016/03/18/eu-turkey-statement/, (08.10.2020).

78 Council of the European Union, "Council Decision on establishing provisional measures in the area of international protection for the benefit of Italy and Greece",12098/15, 22 September 2015. 
not changing the Dublin system ${ }^{79}$. The scheme had a decided-upon quota of 120.000 asylum seekers, and this was supposed to be delegated among the member states in a timeframe of two years. ${ }^{80}$ However, contrary to the projections, only 32.336 asylum seekers from Italy and 21.524 asylum seekers from Greece were distributed to other member states during the period from October 2015 to November. ${ }^{81}$ Therefore, the EU has failed to relocate asylum seekers by adding a different kind of layer to the Dublin system. Furthermore, it was not possible to reduce internal pressure through the Readmission Agreement. Because even though the EU-Turkey Readmission Agreement was signed in 2013, it was not functionally in force in 2015.

Thus, external migratory pressure and continuous increase in the number of arrivals accompanied with the internal failure of the relocation scheme and the inability to adopt any binding, responsible and sustainable European solution among the member states caused a JDT leading to a new agreement, the EU-Turkey Statement. It led the EU to develop cooperation with third countries on border security and the fight against irregular migration. This is also called the "externalisation" of EU asylum policies. ${ }^{82}$ However, the EU's efforts to overcome the crisis by increasing cooperation with the origin and transit countries of migration through the externalisation was conducted in parallel with the other solidarity oriented common asylum policy efforts within the EU. In other words, externalisation is not the only way to manage the Syrian Refugee Crisis. There are other dimensions such as hotspot approach, establishing a common European list of safe countries of origin etc. ${ }^{83}$ However, due to the scope of this case analysis, the emphasis is placed on externalisation which represents a way to escape the JDT by concluding a Statement outside the EU legal framework. As the JDT theory

79 Sandrino Smeets and Derek Beach, "When success is an orphan: informal institutional governance and the EU- Turkey deal", West European Politics 43, no 1 (2020): p. 130.

80 European Commission, "Relocation: EU Solidarity Between Member States", Press Release November 2017, https://ec.europa.eu/home-affairs/sites/homeaffairs/files/whatwe-do/policies/european-agenda-migration/20171114_relocation_eu_solidarity_between member states en.pdf, (01.10.2020).

81 Ibid.

82 Christina Boswell, "The 'external dimension' of EU immigration and asylum policy", International Affairs 79, no 3 (2003): p. 622.

83 European Commission, "A European agenda on migration", $\operatorname{COM}(2015) 240$ final, 13 May 2015, Brussels. 
stresses that "the judicial law-making has the potential of creating a JDT." ${ }^{4}$ where intergovernmental negotiations combined with supranational centralisation. Therefore, using soft law governance methods is strongly motivated by escaping some of the constraints at the EU level, lowering legislative and sovereignty costs. ${ }^{85}$

Thus, the Statement of 18 March 2016 was put forward as a solution. The Statement indicates that every asylum seeker crossing from Turkey to Greece must be sent back to Turkey regardless of their legal status and claim. For every Syrian asylum seeker being returned to Turkey from Greek islands, another Syrian asylum seeker from Turkey to the EU will be placed. This commitment was named the one-for-one mechanism, a refugee who comes via the Mediterranean Sea from Turkey to Greek Islands is sent back to Turkey and settled under temporary protection. In return, the EU resettle one Syrian refugee for every Syrian refugee resettled in Turkey. For the refugees, it gives them access to basic rights and humanitarian aid in Turkey under the Statement's funding allocation, distributed from the EU. From the EU side, there are numerous commitments: re-energising accession talks, accelerating visa liberalisation for Turkish citizens to the Schengen Area, resettling up to 72,000 refugees directly from Turkey and providing up $€ 6$ billion financial support to be used for the needs of asylum seekers. ${ }^{86}$

This was a game changer in terms of new arrivals. The statistical data shows that in comparison with 2015, when the irregular migration flow reached its peak, the subsequent numbers decreased after the implementation of the EU-Turkey Statement. The average daily arrival was approximately 1,740 in the weeks before the implementation of the Statement, it decreased to 47 as of May $1^{\text {st }}, 2016 .{ }^{87}$

The sharp decrease in numbers might give the impression at first sight that the Statement is efficient. However, the fragile design and numerous deficiencies in the Statement, makes the Statement a contested option. Firstly, the member states undermine the supranational institutions in order

84 Scharpf, 2011, p. 227

85 Slominski and Trauner, 2020, p. 94.

86 For this paragraph please see. Council of the European Union, 2016.

87 European Commission, "Implementing the EU-Turkey Statement -Questions and Answers", Press Release of 15 June 2016, https://ec.europa.eu/commission/presscorner/ detail/el/MEMO_16_963, (09.10.2020). 
to overcome the JDT. Concluding the Statement outside the EU's legal framework led the ECJ and the EP to stay out of its scrutinisation process. On the one hand, non-involvement of the ECJ hinders judicial scrutiny, makes it difficult to identify legal responsibility and creates what Sundberg Diez (2019) calls a "growing accountability gap". ${ }^{88}$ On the other hand, noninvolvement of the EP creates democratic accountability gap due to the fact that it was not approved by the EP nor debated in national parliaments. ${ }^{89}$ Hence, these gaps not only deprive the Statement of the EU's guidance, but also makes it fragile and uncertain.

Secondly, it is unclear to what extent the right of Syrian refugees is guaranteed in line with the international refugee protection regime. In this regard, the EU-Turkey Statement has been subject to considerable criticism by many human rights organisations in terms of collective expulsions. Even though the collective expulsion of refugees legally forbidden under Article 4 of the ECHR, collective expulsion of refugees from Greece to Turkey leads to a violation of the principle of non-refoulement and protection against collective expulsion in practice. ${ }^{90}$

Lastly, the Statement has numerous commitments to Turkey that are mostly tied through "issue linkage" which is adding other criteria in agreement to persuade the other side. ${ }^{91}$ The Statement links topics ranging from the re-energising of accession negotiations to the upgrading of the EUTurkey Customs Union. Despite more than the four years passed, most of the objectives have not met, according to the Commission's latest report on the implementation of the Statement. ${ }^{92}$ This situation makes Turkey reluctant to remain committed to the Statement and to block the migration route. In this regard, a recent study on the soft law approach in the context of informal

88 Olivia Sundberg Diez, 2019, p. 4.

89 Ibid., pp.4-5.

90 Amnesty International, “A Blueprint for Despair: The Human Rights Impact of the EUTurkey Deal”, EUR 25/5664/2017, https://www.amnesty.org/download/Documents/ EUR2556642017ENGLISH.PDF, (09.10.2020), pp. 18-19.

91 James Hampshire, "Speaking with one voice? The European Union's global approach to migration and mobility and the limits of international migration cooperation", Journal of Ethnic and Migration Studies 42, no 4 (2016): p. 572.

92 European Commission, "EU-TURKEY Statement: Four years on", March 2020, https://ec.europa.eu/home-affairs/sites/homeaffairs/files/what-we-do/policies/europeanagenda-migration/20200318_managing-migration-eu-turkey-statement-4-years-on_en.pdf (10.10.2020). 
return deals underlines the fact that third country governments may not fulfil obligations due to the non-binding legal nature of agreements and limited options for enforcement. ${ }^{93}$ Translating this into the Statement context indicates that the soft law approach may not boost the problem-solving capacity; the possibility of the EU facing a new pressure is high. ${ }^{94}$ Therefore, Turkey's decision to open its border for asylum seekers to enter Greece in early March 2020 constitutes an example of how the Statement offers a short-term and fragile solution.

When the JDT is taken into account with regard to reforming the asylum system, the Statement at least partially reduced pressure on the asylum system. However, the fragile structure of the EU-Turkey Statement originating from lack of judicial scrutiny and democratic accountability, violation of human rights and not keeping ambitious commitments offers escape to member states for a limited time. Therefore, these deficiencies of the Statement make it contested option rather than the best solution to the JDT.

\section{Case Study Three: The Attitude of Hungary}

This case study examines Hungary's unilateral approach to escaping the JDT, which has restrictive practices. When the irregular migration to Europe reached its peak in 2015, Hungary has become a transit country due to its geographical location. Hungary received the second-highest number of asylum applications with 174,435 applications after Germany with 441,800 asylum applications. ${ }^{95}$ Eventually, this situation started to overburden Hungary, for escaping the core responsibilities attributed to the member states by the Dublin System. The transfer from the EU member states to Hungary was indefinitely suspended on June $23^{\text {th }}, 2015 .{ }^{96}$

This decision was followed by border restrictions in September 2015. The Hungarian government declared a "crisis situation caused by mass immigration" on its Southern border on September 15 $5^{\text {th }}, 2015$ and a 175-

93 Slominski and Trauner, 2020, p. 98.

94 Ibid.

95 Elspeth Guild and Sergio Carrera, "Rethinking Asylum Distribution in the EU-Shall We Start with the Facts?", CEPS Commentary, 17 June 2016, p. 4

96 Hungary Ministry of Interior, "Hungary is suspending re-admission of asylum-seekers from other EU Member States", 23 June 2015, https://www.kormany.hu/en/ministry-ofinterior/news/hungary-is-suspending-re-admission-of-asylum-seekers-from-other-eumember-states, (24.06.2020). 
kilometre long 4-metre high steel barbed wire fence was built within a few days on the border between Hungary and Serbia in order to prevent the crossing of illegal immigrants. ${ }^{97}$ Additionally, a 41-kilometre long barbed wire fence was erected between Hungary and Croatia on September $18^{\text {th }}$, 2015. ${ }^{98}$ In fact, in accordance with the Schengen Border Code ${ }^{99}$, the member states are allowed to temporarily reinstall the border control "in the case of a serious threat to public policy or internal security" limited up to six months under Article 23. Although the border controls usually meant to be temporary, in the context of the migration crisis it was not meant to be temporary. In other words, the member states were in favour of reintroduction of border controls and keeping it as long as the EU has the issue of migration.

Hungary from the political point of view framed the issue mostly in the discourse of border protection. The Hungarian Prime Minister Viktor Orban stated that "We would like Europe to be preserved for the Europeans. But there is something we would not just like, but we want because it only depends on us: we want to preserve a Hungarian Hungary." ${ }^{100} \mathrm{He}$ has played a leading role in exclusionary and restrictive policies against refugees to make the country less attractive for them. Under his leadership, the Hungarian Parliament approved the law authorising the government to deploy the army, allowing police forces to use plastic bullets and tear gas against asylum seekers on September $22^{\text {nd }}, 2015 .{ }^{101}$ Moreover, Hungarian Asylum Act was amended in 2015 in order to establish a transit zone for asylum seekers at the external border and not allow them to enter Hungary. ${ }^{102}$

97 Please see. Government Decree 269/2015 of 15 September 2015 Announcing a Crisis Situation Caused by Mass Immigration and Establishing the Rules related to the Declaration.

98 Amnesty International, "Fenced Out: Hungary's violations of the rights of refugees and migrants", EUR 27/2614/2015, p. 7, https://www.amnesty.org/download/Documents/ EUR2726142015ENGLISH.pdf, (10.10.2020),

99 Council Regulation (EC) No 562/2006.

${ }^{100}$ Cas Mudde, "The Hungary PM made a 'rivers of blood' speech ... and no one care", The Guardian, 30 July 2015.

${ }^{101}$ John Hall, "Hungary passes law allowing army to use stun grenades, rubber bullets and tear gas on migrants, as refugee crisis forces German rail operator to suspend services to and from Austria and Hungary", Daily Mail, 22 September 2015.

${ }^{102}$ United Nations High Commissioner for Refugees -UNHCR, "Hungary As a Country of Asylum- Observations on restrictive legal measures and subsequent practice implemented 
In addition to national measures, Hungary consistently opposed all mechanisms (such as an emergency relocation system) for allocating asylum seekers between the member states in the European context. This occurred despite the Council vote on its decision on the basis of Article 78(3) of TFEU and by QMV. Hungary's rejection is based on "violation of the principle of subsidiarity and disregard for the rights of national parliaments vis -à-vis European legislation". ${ }^{103}$ Based on these reasons, Hungary had not received any asylum seekers from other member states and the Commission launched an infringement procedure not only against Hungary but also other non-cooperative member states, i.e. Poland, Slovakia, Czechia, that failed to comply with the relocation scheme in 2017. ${ }^{104}$ Hungary (C-647/15) and Slovakia (C-643/15) brought an action before the ECJ, but they were dismissed by the Court stating that Hungary and Slovakia are obliged to adopt the relocation scheme. ${ }^{105}$ While Hungary and Slovakia are still failing to fulfil their responsibility, infringement procedures against are still in progress. This situation presents another example of a JDT in the field of asylum. As Scharpf argues that coordinated action or failure depends on the interaction of the capabilities of various actors. ${ }^{106}$ Therefore, he argues that "constellations" change in accordance with the level of harmony and conflict between the member states. ${ }^{107}$ The JDT is still present as a result of the continued contestation.

From the Hungarian point of view, the adoption of radical measures can be seen as a benefit, since drastic changes emerged in the number of asylum seekers. In comparison to 2015, almost six times fewer asylum seekers (29.432) reached the Hungarian border in 2016. ${ }^{108}$ With a gradual decline

between July 2015 and March 2016", May 2016, p.8, https://www.refworld.org/ pdfid/57319d514.pdf, (10.07.2020).

103 Mark Zoltán-Kékesi, "Hungary: Migration and the policy of closed borders", Association for International Affairs Briefing 18, November 2017, p.2.

${ }^{104}$ European Commission, "Relocation: Commission launches infringement procedures against the Czech Republic, Hungary and Poland", Press Release June 2017, https://ec.europa.eu/commission/presscorner/detail/DA/IP_17_1607, (08.09.2020).

${ }^{105}$ Court of Justice of the European Union, 2017.

${ }^{106}$ Scharpf, 2011, p. 221.

${ }^{107}$ Ibid.

${ }^{108}$ Silvia Borbély, "Integration of Refugees in Greece, Hungary and Italy", European Parliament Policy Department A: Economic and Scientific Policy, 2017, p.11, https:/www.europarl.europa.eu/RegData/etudes/STUD/2017/614194/IPOL_STU(2017)61 4194(ANN02)_EN.pdf, (10.10.2020). 
over the years, the number of asylum applicants fell to 468 in 2019. ${ }^{109}$ However, this situation is not perceived in a positive manner from the human rights and EU perspective. On the one hand, from the perspective of human rights, Hungary has been subjected to criticism in terms of failing to fulfil its legal and humanitarian responsibilities deriving from the EU legislation and international human rights obligations. Numerous human rights organisations have also raised their voice against inadequate conditions of detention centres, violation of the principle of non-refoulement, the humiliation of asylum seekers, disproportionate physical violence. ${ }^{110}$ On the other hand, from the EU's point of view, Hungary has moved away from the principle of "solidarity". Therefore, this can be seen as an important turning point in setting a precedent for other anti-immigrant EU countries. Besides, radical practices against the Schengen principles have led to the questioning of the future of the EU. Therefore, the unilateral approach for escaping the JDT may only be of "benefit" for the country acting so self-interested.

\section{Conclusion}

This research has been concerned with the question of the extent the EU has managed to mitigate the deficiencies of the Dublin System in the aftermath of the 2015 Syrian Refugee Crisis. The poor design of the current Dublin System, accompanied by the absence of any meaningful political will to reform, has resulted in an increase of pressure on the system itself. The migration crisis in 2015 showed that the system collapsed under its own weight, faced with an increase in arrival numbers of asylum seekers. It needed to start operating on a larger scale. Thus, the collapse of the system was triggered by an exceptionally high number of applicants as a result of an administration and bad preparation for the high numbers of migrant arrivals. However, structural reasons show that, first and foremost, the issue was the lack of political will among the member states to undertake a concerted action to address the flaws of the Dublin system.

As the recast of the Dublin III Regulation was blocked by the Council, the lack of political will was evident. This defines the JDT. Even though the Commission withdrew the recast and proposed the New Pact to exit the JDT,

\footnotetext{
109 The European Council on Refugees and Exiles-ECRE, "Applications and granting of protection status at first instance: 2019 ", https://www.asylumineurope.org/reports/country/hungary/statistics\#_ftn1, (19.06.2020). ${ }^{110}$ UNHCR, 2016; Amnesty International, 2015.
} 
the core of the policy is preserved, and the political divisions regarding responsibility sharing are still prominent in the New Pact. Therefore, it is seen as "old wine in new bottles" themselves in a JDT. Starting from this point, the research aimed to examine the alternative ways to make asylum policies more functional when there is no chance to proceed with legislative changes. The findings clearly indicated that the JDT is active where either national governments are in power or the interests of member states diverge with each other and supranational institutions. ${ }^{112}$ The combination of findings provides some support for the theoretical understanding of historical institutionalism that in case a decision is adopted, it is difficult to change it due to its "stickiness". ${ }^{113}$ Building on these theoretical understandings, the empirical findings in this research provide an essential understanding of escaping the JDT in the field of asylum. Adapting the framework of Trauner published in 2011, the research has provided alternative ways to escape JDTs through different cases.

The Malta Agreement has demonstrated the attempt of a group of member states to break the JDT through adopting a differentiated form of cooperation as an "ad hoc initiative" outside of the EU framework. While it has led to limited achievement in practice by highlighting a commitment to save human lives by some member states, the informal and flexible nature combined with limited transparency and systematic oversight makes the Malta Agreement, not the best option.

The EU-Turkey Statement has shown another alternative way of escaping the JDT through externalisation. Under migratory pressure, concluding a statement with the main country of transit migration led to a substantial decrease in arrivals in the EU. However, a mere reduction in the number of irregular migrants arriving at EU's shores does not prove that the Statement is sustainable and efficient. Similar to the first case, the informal nature of the agreement raises legitimate concerns with regard to violation of human rights and relying heavily on Turkey's commitment through a wider range of pledges, lack of judicial scrutiny, transparency, accountability. Therefore, this case study provides a partial response to exit the JDT.

\footnotetext{
${ }^{111}$ Christopher Hein, "Old wine in new bottles? Monitoring the debate on the New EU Pact on Migration and Asylum", Heinrich-Böll-Stiftung, 16 June 2021.

112 Scharpf, 1998 ;2006; 2011.

113 Pierson, 1996.
} 
The attitude of Hungary had indicated the unilateral action of a member state to decrease the number of incoming asylum seekers. From the Hungarian point of view, restrictive measures, i.e. closing borders, provides a quick solution to stop irregular migration. However, these measures have important implications with regard to solidarity and human rights. Hungary is breaking away from EU values and threatens the future of the EU with violation of solidarity. Unilateral restrictive measures towards asylum seekers disregard basic human rights. Therefore, following radical measures for avoiding dealing with domestically contentious issues, such as refugee quotas, only "benefit" the country that follows those practices.

These empirical findings in the research are significant in two respects. Firstly, case studies have shown that informal arrangements, i.e. Malta Agreement, the EU-Turkey Statement are seen as an alternative option for the member states to overcome the JDT. Although exit mechanisms make a difference in overcoming a deadlock in the policy field, they cannot be considered the best solution for addressing possible future mass migrations. In this regard, unlike the first two case studies, the unilateral action of Hungary may only be of "benefit" for the country itself despite its implications in terms of undermining solidarity and disregarding human rights. Therefore, alternative solutions only provide a partial response rather than a full exit from the JDT.

Lastly, these results confirm the difficulty to reach a compromise when it comes to the asylum. This situation provides further support why consensus might only be "reached on solutions which are deficient compared to the potentially attainable collective optimum". ${ }^{114}$ This explains why member states are caught with JTD in the asylum field. As Scharpf stresses that "if transaction costs are high, policy outcomes are likely to be suboptimal." 115

114 Scharpf, 2011, p. 222.

${ }^{115}$ Ibid. 


\section{Bibliography}

Amnesty International, “A Blueprint for Despair: The Human Rights Impact of the EU-Turkey Deal”, EUR 25/5664/2017, https://www.amnesty.org/download/ Documents/EUR2556642017ENGLISH.PDF, (09.10.2020).

Amnesty International, “Fenced Out: Hungary's violations of the rights of refugees and migrants", EUR 27/2614/2015, https://www.amnesty.org/download/ Documents/EUR2726142015ENGLISH.pdf, (10.10.2020).

Beşgür, Elif Cemre, "Alternative Routes to Escape the Joint Decision Trap in the Field of Asylum", Unpublished master's thesis, Brussel, Vrije Universiteit Brussel, Faculty of Social Sciences, 2020.

Beşgür, Elif Cemre, "Alternative Routes to Escape the Joint Decision Trap in the Field of Asylum", Jean MonneThesis, June 2021, https:/www.jeanmonnet.org.tr/ portals/0/yayinlar/JEAN\%20MONNE\%20THESIS\%205.pdf (19.06.2021).

Beşgür, Elif Cemre and Utkulu Utku, "Esnek Entegrasyon Temelinde Avrupa Birliği'nin Geleceği Ve Türkiye'nin Yeri: Muhtemel Senaryolar”, Ankara Avrupa Çalışmaları Dergisi 18, no 2 (2020): 325-364 .

Borbély, Silvia, "Integration of Refugees in Greece, Hungary and Italy", European Parliament Policy Department A: Economic and Scientific Policy, 2017, https://www.europarl.europa.eu/RegData/etudes/STUD/2017/614194/IPOL_S TU(2017)614194(ANN02)_EN.pdf, (10.10.2020).

Boswell, Christina, "The 'external dimension' of EU immigration and asylum policy", International Affairs 79, no 3 (2003): 619-638.

Carrera, Sergio and Cortinovis Roberto, "The Malta declaration on SAR and relocation: A predictable EU solidarity mechanism?", CEPS Policy Insight, No. 2019-14/October 2019.

Catani, Andrea, “The so-called "Malta Agreement": four months later", 24 February 2020, https://www.sirius-project.eu/news/so-called-malta-agreement-fourmonths-later, (01.07.2020).

Convention Determining the State Responsible for Examining Applications for Asylum Lodged in One of the Member States of the European Communities, OJ C 254/01, 1990.

Council of the European Union, "Justice and Home Affairs Council Meeting", 7-8 October 2019. 
Council of the European Union, "Council Decision on establishing provisional measures in the area of international protection for the benefit of Italy and Greece",12098/15, 22 September 2015.

Council of the European Union, "EU-Turkey Statement, 18 March 2016", https://www.consilium.europa.eu/en/press/press-releases/2016/03/18/euturkey-statement/, (08.10.2020).

Council of the European Union, "Outcome of the Justice and Home Affairs Council Meeting", 12837/19, Luxembourg, 7 October 2019.

Council Regulation (EC) No 343/2003 of 18 February 2003 establishing the criteria and mechanisms for determining the Member State responsible for examining an asylum application lodged in one of the Member States by a third-country national, OJ L 50/1.

Council Regulation (EC) No 562/2006 of the European Parliament and of the Council of 15 March 2006 establishing a Community Code on the rules governing the movement of persons across borders (Schengen Borders Code), OJ L 105.

Council Regulation (EU) No 604/2013 of the European Parliament and the Council of 26 June 2013 Establishing the Criteria and Mechanisms for Determining the Member State Responsible for Examining an Application for International Protection Lodged in one of the Member States by a Third-Country National or a Stateless Person (recast), OJ L 180/31.

Court of Justice of the European Union, "Slovak Republic and Hungary v Council of the European Union", Judgement of the Court of C-643/15 and C-647/15, 6 September 2017.

ECRE, "Applications and granting of protection status at first instance: 2019", https://www.asylumineurope.org/reports/country/hungary/statistics\#_ftn1, (19.06.2020).

European Commission, “A European agenda on migration”, COM(2015) 240 final, 13 May 2015, Brussels.

European Commission, "Communication from the Commission to the European Parliament, the Council, the European Economic and Social Committee and the Committee of the Regions on a New Pact on Migration and Asylum", COM(2020) 609 final, 23 September 2020, Brussels.

European Commission, "Communication from the Commission to the European Parliament and the Council towards a Reform of the Common European 
Asylum System and Enhancing Legal Avenues to Europe”, COM (2016) 197 final, Brussels.

European Commission, "Proposal for a Regulation of the European Parliament and of the Council on asylum and migration management and amending Council Directive (EC) 2003/109 and the proposed Regulation (EU) XXX/XXX [Asylum and Migration Fund]", COM(2020) 610 final, Brussels.

European Commission, "Relocation: EU Solidarity Between Member States", Press Release November 2017, https://ec.europa.eu/homeaffairs/sites/homeaffairs/files/what-we-do/policies/european-agendamigration/20171114_relocation_eu_solidarity_between_member_states_en.pdf , (22.09.2020).

European Commission, "Relocation: Commission launches infringement procedures against the Czech Republic, Hungary and Poland", Press Release June 2017, https://ec.europa.eu/commission/presscorner/detail/DA/IP_17_1607, (08.09.2020).

European Commission, "EU-TURKEY Statement: Four years on", March 2020, https://ec.europa.eu/home-affairs/sites/homeaffairs/files/what-wedo/policies/european-agenda-migration/20200318_managing-migration-euturkey-statement-4-years-on_en.pdf (10.10.2020).

Falkner, Gerda (ed.), The EU's Decision Traps: Comparing Policies, Oxford University Press, 2011.

FRONTEX, “Risk Analysis for 2017”, 2133/2017, Warsaw.

Hall, John, "Hungary passes law allowing army to use stun grenades, rubber bullets and tear gas on migrants, as refugee crisis forces German rail operator to suspend services to and from Austria and Hungary", Daily Mail, 22 September 2015.

Hampshire, James, "Speaking with one voice? The European Union's global approach to migration and mobility and the limits of international migration cooperation", Journal of Ethnic and Migration Studies 42, no 4 (2016): 571586.

Hein, Christopher, "Old wine in new bottles? Monitoring the debate on the New EU Pact on Migration and Asylum", Heinrich-Böll-Stiftung, 16 June 2021.

Hungary Ministry of Interior, "Hungary is suspending re-admission of asylumseekers from other EU Member States", 23 June 2015, https://www.kormany.hu/en/ministry-of-interior/news/hungary-is-suspendingre-admission-of-asylum-seekers-from-other-eu-member-states, (24.06.2020). 
Joint Declaration of Intent on a Controlled Emergency Procedure-Voluntary Commitments by Member States for a Predictable Temporary Solidarity Mechanism, 2019, Valletta.

Geddes, Andrew, "Migration: differential Institutionalisation and Its Effect" in Policy Change in the Area of Freedom, Security and Justice: How EU Institutions Matter, Florian Trauner and Adriana, Ripoll Servent (eds.), pp. 73-90, London: Routledge, 2015.

Guild, Elspeth and Carrera Sergio, "Rethinking Asylum Distribution in the EU-Shall We Start with the Facts?”, CEPS Commentary, 17 June 2016.

Government Decree 269/2015 of 15 September 2015 Announcing a Crisis Situation Caused by Mass Immigration and Establishing the Rules related to the Declaration.

Jean Monnet Memoirs, translation. R. Mayne Garden City: Doubleday \& Company, 1978, p.417, cited Gerda Falkner, “The EU's current crisis and its policy effects: research design and comparative findings", Journal of European Integration 38, no 3 (2016): 219-235.

Mudde, Cas, "The Hungary PM made a 'rivers of blood' speech ... and no one care", The Guardian, 30 July 2015.

Müller, Patrick and Slominski, Peter, "Agree now - pay later: escaping the joint decision trap in the evolution of the EU emission trading system", Journal of European Public Policy 20, no 10 (2013): 1425-1442.

Neill, Nugent, The Government and politics of the European Union, London: Palgrave, 1999.

Peters, B. Guy, "Escaping the joint decision trap: Repetition and Sectoral politics in the European Union", West European Politics 20, no 2 (1997): 22-36.

Pierson, Paul, "The Path to European Integration: A Historical Institutionalist Analysis", Comparative Political Studies 29, no 2 (1996): 123-163.

Pierson, Paul, "Increasing Returns, Path Dependence, and the Study of Politics", American Political Science Review 94, no 2 (2000): 251-267.

Pollack, Mark A., "Creeping competence: the expanding agenda of the European Community", Journal of Public Policy 14, no 2 (1994): 95-145.

Scharpf, Fritz W., “The Joint-Decision Trap: Lessons from German Federalism and European Integration”, Public Administration 66, no 3 (1998): 239-278.

Scharpf, Fritz W., "The Joint-Decision Trap Revisited", JCMS: Journal of Common Market Studies 44, no 4 (2006): 845-864. 
Scharpf, Fritz W., "The joint decision trap model: context and extensions" in The EU's Decision Traps: Comparing Policies, ed. Gerda Falkner, pp. 217-237, Oxford: Oxford University Press, 2011.

Schimmelfennig, Frank, Leuffen Dirk and Rittberger Berthold, "The European Union as a system of differentiated integration: interdependence, politicization and differentiation", Journal of European Public Policy 22, no 6 (2015): 764 782 .

Smeets, Sandrino and Beach, Derek, "When success is an orphan: informal institutional governance and the EU- Turkey deal", West European Politics 43, no 1 (2020): 129-158.

Slominski, Peter and Trauner, Florian, "Reforming me softly - how soft law has changed EU return policy since the migration crisis", West European Politics 44, no 1 (2020): 93-113.

Stubb, Alexander, "A Categorization of Differentiated Integration", Journal of Common Market Studies 34, no 2 (1996): 283-295.

Sundeberg, Diez Olivia, "Diminishing safeguards, increasing returns: Nonrefoulement gaps in the EU return and readmission system", EPC Discussion Paper, 4 October 2019.

Sundeberg, Diez Olivia and Trauner Florian, "EU return sponsorships: High stakes, low gains?”, EPC Discussion Paper, 19 January 2021.

Trauner, Florian, "Increased Differentiation as an Engine for Integration" in The EU's decision traps: comparing policies, Gerda Falkner (ed.), pp. 145-160. Oxford: Oxford University Press, 2011.

Trauner, Florian, “Asylum policy: the EU's 'crises' and the looming policy regime failure”, Journal of European Integration 38, no 3 (2016): 311-325.

Uçarer, Emek M., "Justice and Home Affairs" in European Union Politics, Michelle Cini and Nieves, Perez-Solorzano Barragán (eds). pp. 306-323, 3rd ed, Oxford: Oxford University Press, 2010.

UNHCR, "Hungary As a Country of Asylum- Observations on restrictive legal measures and subsequent practice implemented between July 2015 and March 2016”, May 2016, https://www.refworld.org/pdfid/57319d514.pdf, (10.07.2020).

Natascha, Zaun, "States as Gatekeepers in EU Asylum Politics: Explaining the Nonadoption of a Refugee Quota System", JCMS: Journal of Common Market Studies 56, no 1 (2018): 44-62. 
Zaun, Natascha and Roos Christof, "Immigration Policy and European Union Politics" in Oxford Research Encyclopedia of Politics, Oxford: Oxford University Press, 2019.

Zoltán-Kékesi, Mark, "Hungary: Migration and the policy of closed borders", Association for International Affairs Briefing 18, November 2017. 